\title{
アルミニウム及その合金の阷極防蝕に就て
}

\section{ON THE CATHODIC PROTECTION OF ALUMINIUM AND ITS ALLOYS}

\section{伊 $\mathrm{OR}$ 藤 $\stackrel{\text { 伍 }}{\mathrm{T}}$ 郎*}

The cathodic protective method for aluminum and its alloys from corrosion in various electrolyte solution was studied. In general the cathodic current density of adequete maznitude applied by the external e. m. f. can fairly protect aluminum and its alloys from corrosion in various so'utions except the alkali. In the case of salt so'utions for example sodium chloride, aluminum can a'so be pro'ected by cathodic current, provided that the current density is not too high. If the current density excesd the liniting value, the cathodic corrosion does occur. The condition nesessary to protect aluminum and its alloys from corrosion in various solutions can be summerized as follows.

Table 1

\begin{tabular}{l|c|c|c|c|c|c|c}
\hline & $\mathrm{NaCl}$ & $\mathrm{NH}_{4} \mathrm{Cl}$ & $\mathrm{ZnCl}_{2}$ & \multicolumn{2}{|c|}{$\mathrm{HCl}$} & $\mathrm{NaOH}$ \\
\hline Electrolyte & \multicolumn{2}{|c|}{$0.5 \mathrm{~N}$} & $1 \mathrm{~N}$ & $1 \mathrm{~N}$ & $0.1 \mathrm{~N}$ & $0.5 \mathrm{~N}$ & $0.005 \sim 0.1 \mathrm{~N}$ \\
\hline Alloy & for $\mathrm{Al}$ & for 24S & & \multicolumn{2}{|c|}{ for $\mathrm{Al}$} \\
\hline $\begin{array}{l}\text { Protective cu- } \\
\text { rrent density } \\
\left(\mu \mathrm{A} / \mathrm{cm}^{2}\right)\end{array}$ & $2 \sim 7$ & $3 \sim 6$ & $>8$ & $>35$ & $>450$ & $>5000$ & \\
\hline $\begin{array}{l}\text { Protective Po- } \\
\text { tential refered } \\
\text { to 1N Calomel } \\
\text { Cel 1 (V) }\end{array}$ & $-0.9 \sim 1.4$ & $\begin{array}{r}-0.65 \sim \\
-0.70\end{array}$ & $<-0.9$ & $<-1.08$ & $<-0.9$ & $<-0.9$ & Impossible \\
\hline
\end{tabular}

Contact of aluminum and its alloys with baser metals such as zinc can also protect aluminum, for the actual measurement of the current through the circuit oi these combined metals and alloys showed just the same amount as mentioned in the above tajle. The cathodic current of the alclad duralmin core afforded by alu:ninum coating is also in the range of protective condition ass hown in the above taỏle. In fact the excellent corrosion resistance of alclad alloys can be attributed partially to the cathodic protection of the duralmin core by the aluminuin coating.

In conclusion, the effect of cathodic protection of aluminum and its alloys is essentially the same regardless of whether the current is afforded by an external source or by a dissolving anode of $\mathrm{pr}$ otective me als. But one must be careful that the aluminum and its alloys has both the upper and lower limits for the proteting current in the salt solution. Th: current density above the upper limit produces a bad effect. Contact with a metal which is tos basic to aluminum causes corrosion of the latter. For example. the contact with magnesium accelerates the corrosion of aluminum and its alloys in sodium chloride solution. The coating materials of alclad plate must suppiy the sufficient current to protect the core alloy, but must not exceed the critical value.

These cathodic corrosion of aluminum and its alloys is not due to the reduction of oxide film by atomic hydrozen evolved at the cathode as the case of stainless ste:l, but due to the cathodic production of caustic by electra.ysis of salt so ution by the current of so called cathodic protection.

\section{I 緒 言}

金属の除極防玲以関する着想狋大空古いもので㐫り

(1) 又保護金属学使つ大除極防蝕は相当に広く年用され
て来えが、陰極防蝕の機樥や詳しい必要杀件、ことに外

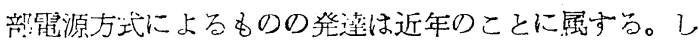
か乙それも多くは銅に関ずるものであつて其の似り金鼠 に就ての研究は少い。アルミニウムに関してはそれ等脏

* 科等研究 所

The Scientific Research Institute 


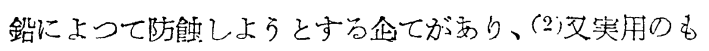

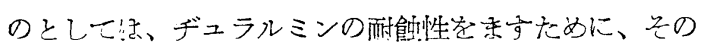

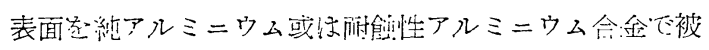
覆したアルクラツド (Alclad) があり、その切口に露出

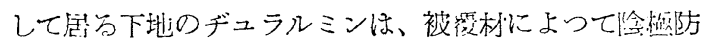

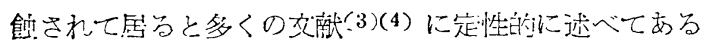
位のものて定星的データは殆どない。渚者将アルミニウ ム及そ合金の陰極防蝕に就てしらべて居るので、現在 迄の結淉ををとめて報告する。

\section{II 外部電源方式によるアルミニウム の防蝕}

試料としては $400^{\circ} \mathrm{C} て ゙ 30$ 分海鈍した市敗純アルミニ ウム板を0番エメリー紙で研想した後、500 $\mathrm{C}$ の10\%苦

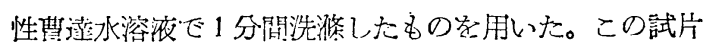

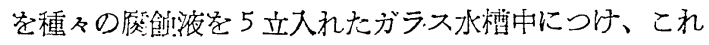

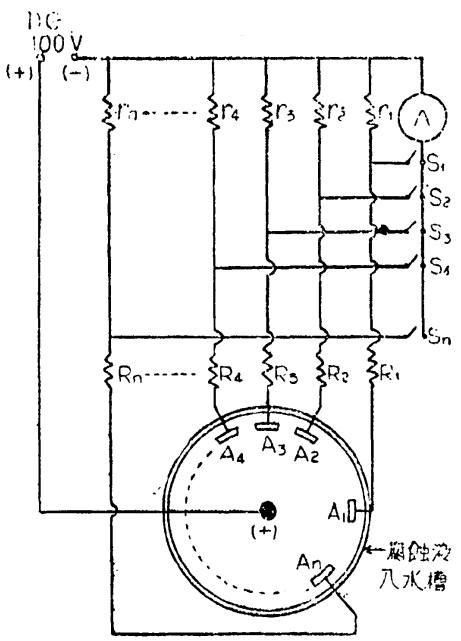

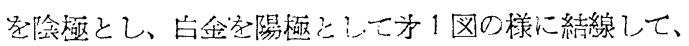

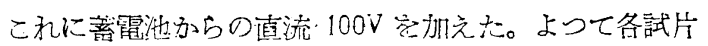

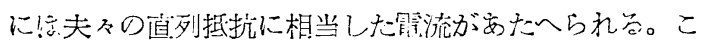

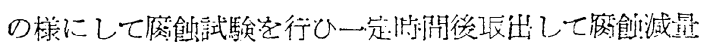

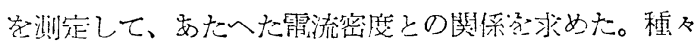

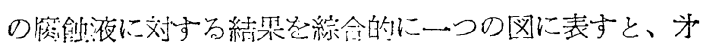

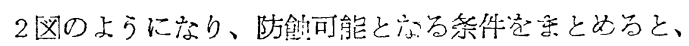
为1坠のようになる。この表からみると、アルミニウム

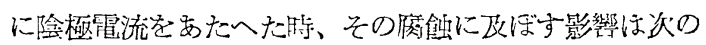
三つにわけられる。

(1) 電流と共に腐鎦の減名埸合

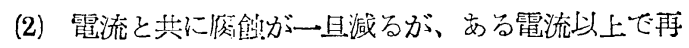
び磨蝕空扣こす培合

(3) 雷流と共に麻领の熄す埸合

(1)及(2)に就ては一定の杀件のもとで、除極防钻方可能 であるが、(3)の埸合は不能であると云うことになる。そ して逆に云えば、(3)は麻领現象が電気化学的なるのでな

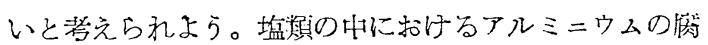
蝕が主として電気化学的であること㥙異詇がないのであ るが、(5)腐蝕試験の結果も除極防刢が有效で西ること穵 示して居る。

例えば食壏水溶液では除極電流密度 $2 \mu \mathrm{A} / \mathrm{cm}^{2}$ 以上学 あたえて 1 规定甘承雷極に対してー0.9V以下に分極さ过 れば臛刢をとめることができる。しかし更に雷流を委し て $7 \mu \mathrm{A} / \mathrm{cm}^{2}$ 以上とし、電位が $-1.4 \mathrm{~V}$ 以下になると、 再び腐蝕がはじまり、それからは急激に磨领がひどくな る。しかし塩酸の㭙には、この様な除極磨蝕が扰こるこ と仿ないし、又塩類でも塩化严鉛や、塩化アンモニウム

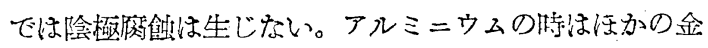
履の昐合とちがつて、防蝕可能鼠流密度攻電位に上限と

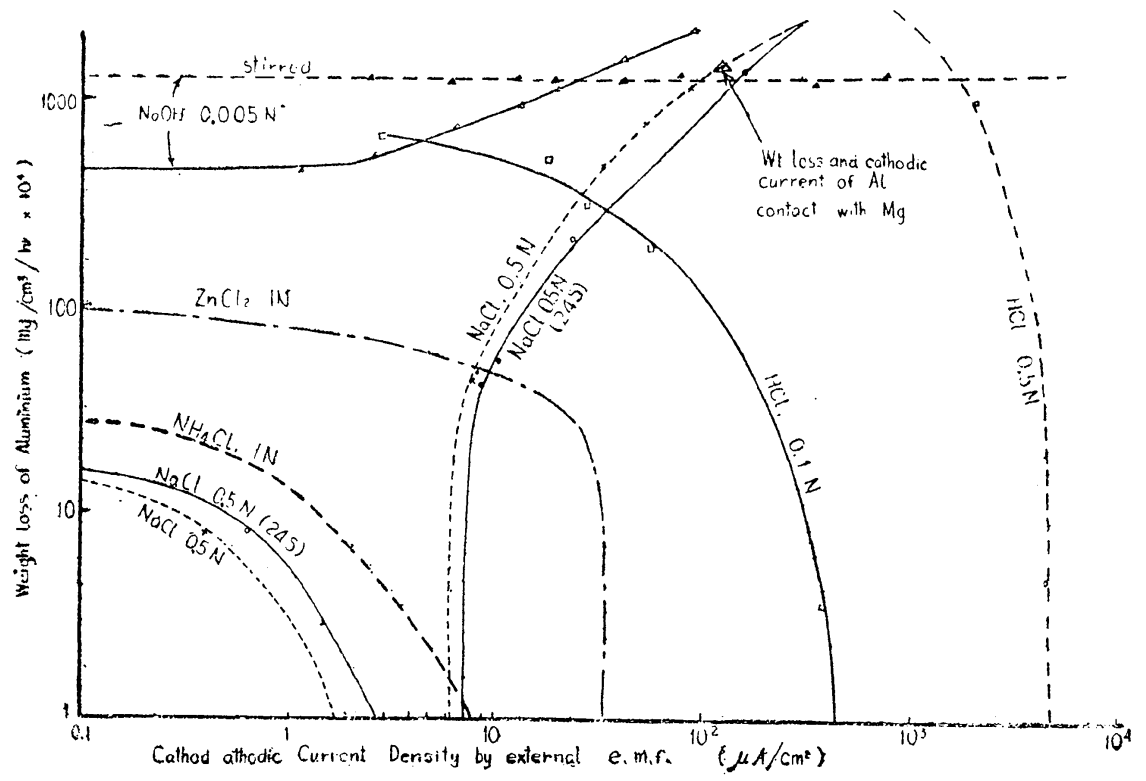

Fig. 2

Weight loss of Aluninum in various Solutions while Cathodic 
下限とが共にあること㐫るの方゙特徴である。

\section{III 陰極腐蝕の理由}

金属面上の雷位の低い点 (anode) と高い点(cathode) と起、外部加方の電流に上る陰極分極によつ七等電位と

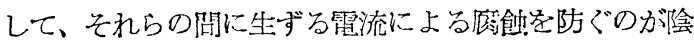
極防蝕の原理であるから、この防蝕法は腐蝕の機構がこ のような電気化学的な㦄蝕雷流による場合だけしか有効 でない。文逆に云えば電気化学的な突赨に対しては必ず 有効な等である。

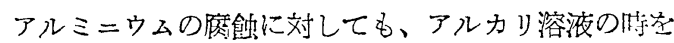
のぞいて、大抵の場合除極防玲は有効であるのだが、食

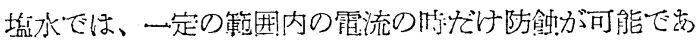

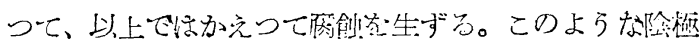

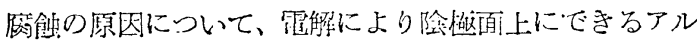

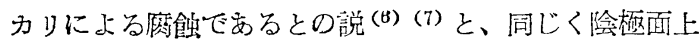
に発生する水素によつてアミルニウムの酸化被膜の被菫 されるためであるとの説とがある。(3)筆者はこの点につ いてたしかめた結果、(9)塩酸中の様に㓌極に水素が盛に 発生する様な、高電流密展になつてはじめて防蝕が可能 になる䄈合のあること中、食塩水中でマグネシウムは除 極腐玲老扣こさないが、アルミニウムと同様な両性金属

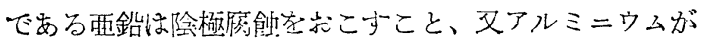

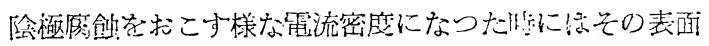
にごく近いところの PH が顕渚にアルカリ性になること などから、アルミニウムの食塩水中における除梳愿蝕惊 電解によつて生じたアルカリ（莎性ソーダ）によるもの であると考えた。

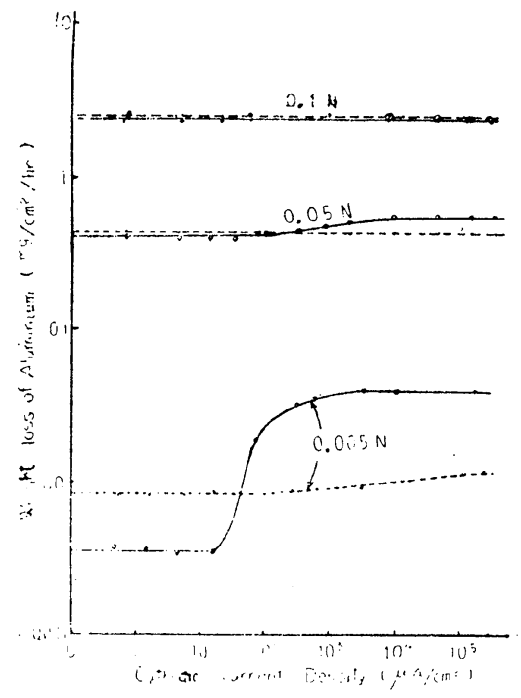

Fig. 3

Weight loss of Aluminum while Cathodic in caustic Soda Solution

(unstirred-full line)

(stirred...dotted line)
一方节性ソーダ水溶液中でルミニウム空陰極にした 封どうなるか居しらべて多ると、为3図の上らになる。

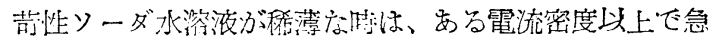

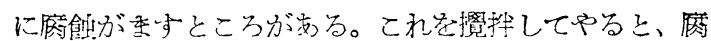

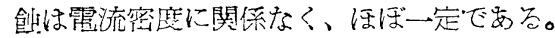

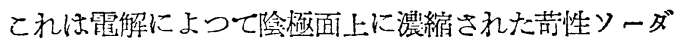
が㩭姓によつてちらされたためと考えられる。䒬性ソー ダが濃く京ると共に、雷解による除極面上の濃度堌加に

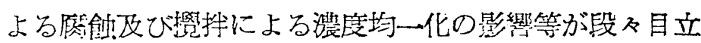
たなくなる。従来の研究によると、(7)アルミニウムを苛

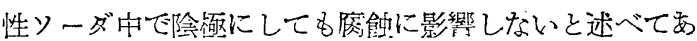
ろが、これ蛙電流密度が $5 \mathrm{~mA} / \mathrm{cm} 2$ 以上の㥞な大きな場

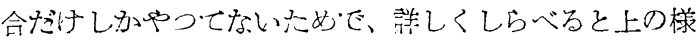
になる。

いづれにしても荊性ソーダ水溶液中ではアルミニウム

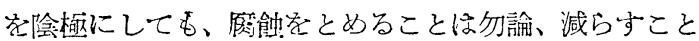

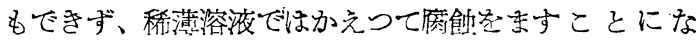
る。

そしてこの漛な結果から考えると、莎性ソーダによる

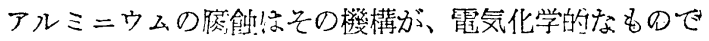
はないであろうと考えられら。食塩水中のアルミニウム

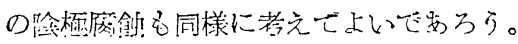

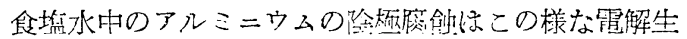

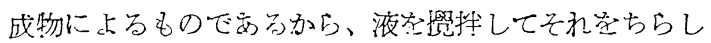

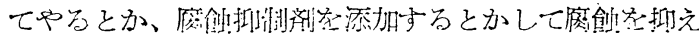
ることが出来る。例六ば企塩水が榑中で迴転する様にモ ーターで摫找して、試片の近くで約 $20 \mathrm{~cm} / \mathrm{sec}$ 位の速さ

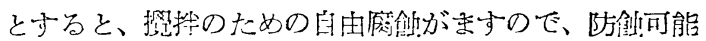

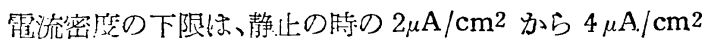

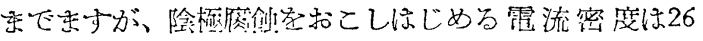
$\mu \mathrm{A} / \mathrm{cm}^{2}$ になり、防领可能電流密度の篹团方昿くなる。こ

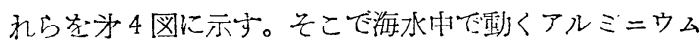
製の物品老防領するような时には、過剩雪流によっ除極 磨领のおそれが非常にすくなくなる。磨领抑制剤として の寒天学食塩水に添加 $(5.4 \mathrm{gr} / 1)$ しても、防創可能霓流の 䉓囲は $1 \mu \mathrm{A} / \mathrm{cm}^{2}$ から $15 \mu \mathrm{A} / \mathrm{cm}^{2}$ 迄㕕げることができる。 尤も同じ除極腐虭とよばれるものでも、酸の中に於け る18〜8不銹鋼の様な時保、水菜による表面被膜の還元 が原因であつて、表面被膜のなくなつて裸となつた不銹 鋼が酸にとけるの゙だるから、その淕合でも反応!電気

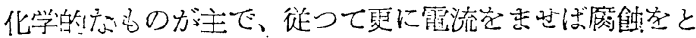
めること分出来危。(10)

\section{IIII保護金属法によるアルミニウムの 陻極防触}

上述の様に種及の喥蝕液に対して、アルミニウムを保 護与るに必要な除極防蝕の条件がわかつから、アルミ 


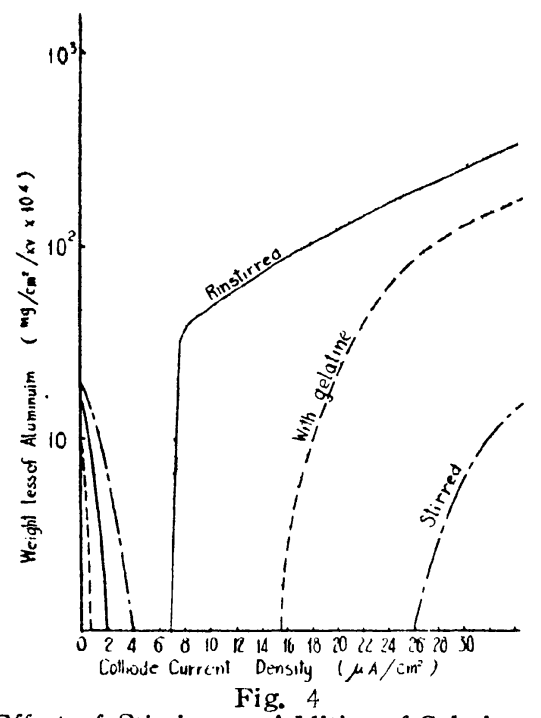

Effect of Stirring or Addition of Gelatine on the Cathodic Corrosion of Alu:ninum in $3 \% \mathrm{NaCl}$ Solution

Table 2

Electrode Potential of Metals in 3\% Nacl Solution refered to in Calomel Cell

\begin{tabular}{c|c}
\hline Metal & Potential (Volt) \\
\hline Mig & -1.67 \\
Mn & -1.31 \\
$\mathrm{Zn}$ & -1.10 \\
$\mathrm{Cd}$ & -0.79 \\
$\mathrm{Al}$ & -0.78 \\
$\mathrm{Fe}$ & -0.68 \\
$\mathrm{~Pb}$ & -0.53 \\
$\mathrm{Cr}$ & -0.43 \\
\hline
\end{tabular}

Table. 3

Current Density of Aluminuin while Cathodic by Contact with Magnesium or Zinc

\begin{tabular}{c|c}
\hline Metal & Current Density $\left(\mu \mathrm{A} / \mathrm{c}: \mathrm{n}^{2}\right)$ \\
\hline $\mathrm{Mg}$ & $200 \sim 300$ \\
$\mathrm{Zn}$ & $5 \sim 6$ \\
\hline
\end{tabular}

ニウム学適当にえらんだこれより電位の低い他の金属と 接触さ过ることにより、この条件杂逆成する様にしても よいわけである。そこで食塩水の䭪合に就て、この様な

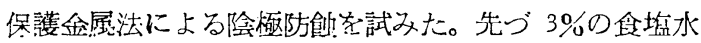

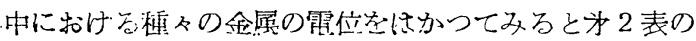

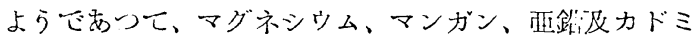
ウムの四つはアルミニウムより霓位多低い。しかしカド ミウムは高価でヌアルミニウムと電位が近すぎっし、マ ンガンも取圾上不便であるので、先づマグネシウムと互 鉛をとりあげてみた。この二つの金属圶アルミニウムと 結んで、食塩水につけた時、アルミニウムにあたえられ

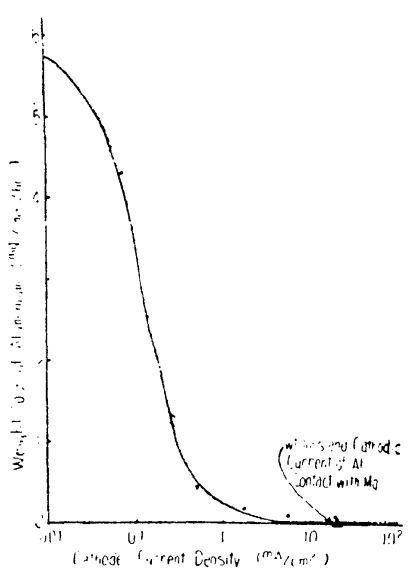

Fig. 6

Fig. 5

fffect of Cathodic Currsupplied by $\mathrm{Zn}$ on the mechanical Propert es of Aluminum

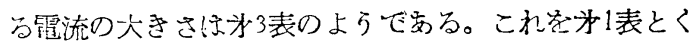
らべてみると、マグネシウムは電流が大きすぎて適当で ないようであるが、亜鈶は丁度よい大さの電流をアルミ ニウムにあたえる。実際に腐蝕試験㐐してみてす、为 1 図に示寸様に、マグネシウムはアルミニウムをかえつて 㦄领与る。そしてその程度はその牊生ずる電流を外部加 らあたへた脖と全く同じ大さである。

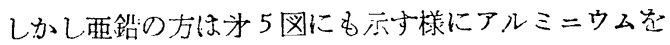
完全に保萑する。尤もマグネシウムがアルミニウムにあ たえっ電流が大きすぎると云つても、これは $3 \%$ 食塩水 の時のことであつて、アルミ゙ニウムの保護にもつと大き

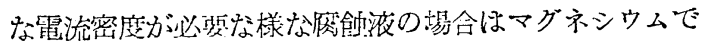
なくては役に占たないこともあろ。例えば㷪酸の堨今が それであつて、0.5規定の㷪酸中のアルミニウム艺外部 電源方式によつて防蝕した为6紣果によると約10 $\mathrm{mA} / \mathrm{cm}^{2}$ 位の電流密度力必要で、要鈶ではとてもとれ だけの電流厓生じないが、マグネシウム学用いれば、約 20: $\mathrm{nA} / \mathrm{cm}^{2}$ の電流䒺アルミニウムにあたえるのて、为 6図に照点で示した样にアルミニウムの防咀ができて。

以上は保護金属として使う早な方の金属の大さのこと にはふれなかつたが、等際に使ら娚合には船艄の船尾に 央用されて居る保護亚鉆の椂に保護す万ものの一部に阥 極となる小さな保護众属爻つけろことになる。もし生ず る保讙雷济の大さが隄桠の大さによつてちがうと、アル ミニウムの場命のように条件のう万さいときには团る。 とこみが食盐水の町には大低の金属が、除極分極の方む゙

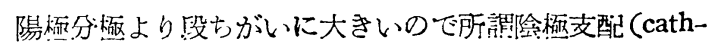
odic control) となつて、保護電流の大さは陽極の大さ には叞係なく、险極の面積に比例する。從つて陽極の大 さが变つても陰㥛の雷流密度は常に一定であるから具合 
がよい。例泣アルミニウムと覀鉛との組合せで、その 間に生ずそ雷流は垔錕の面積には無関倸であるが、アル ミニウムの面積に略比例すること为 7 区のようであるの で陰極となる。アルミニウムの電流密度は一定である。 但し雨者の面積のちがいがあ态り犬゙きくなりすぎるとこ の限りでない。(14)

Fig. 7

Effe $t$ of Anode $(Z n)$ or Cathode (Al) Area on the Corrosion Current of AlZn Couple

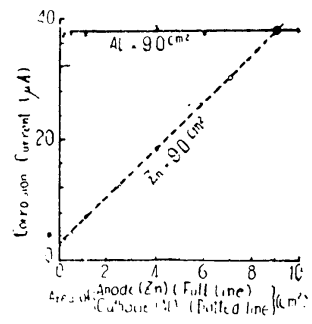

アルミニウムが常に水中につかつて居るのであれば、 その一部に小さな覀鉛片在つけただけでよいのである が、両者の接触部は電流密度が最も大きいので、侵蝕さ れて、導通不艮になつたり、覀鉛氺脱落したりすること が多い。殊に乾湿がくり返される梯な睆には、アルミニ ウムの全面に要鉛をつけてやることが必要である。この ためには垔鉛のメタリコンが最も有効である。(11)

\section{V チュラルミンの場合}

アルミニウム合众に就てもアルミニウムの䐗と同様に

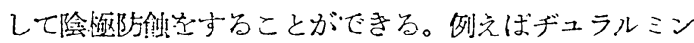

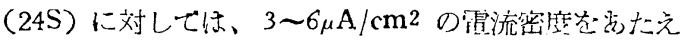

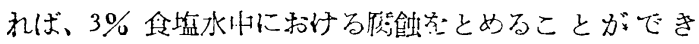

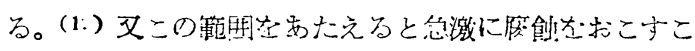

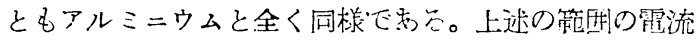

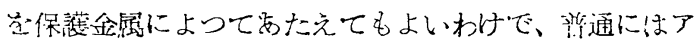
ルミニウムが用いられふ。これがアルクラツドで出る が、この場合にヂュラルミンにあたえられる保護雷浇の 大さは約 $3 \mu \mathrm{A} / \mathrm{cm}^{2}$ で女つて、(12) ちようど上述の防玲 可能電流密度の範囲に入つて居る。亜釦老保護金展とし

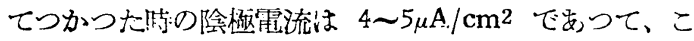
れも上述の範囲内にあり、又実際惋领試験去してみて も、西鉛の防飾胶果忠顕潧でをる。

\section{VI 總括}

アルミニウム及その:食合に対しても险㖶队捈法によつ

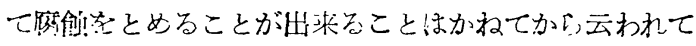

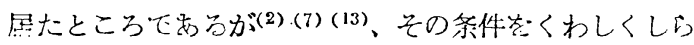

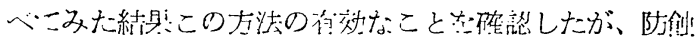

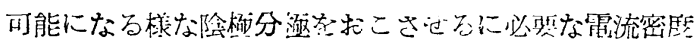
に下限があると共に、上限があることに注意しなくては ならない諹合の变ることがれかつた。即ち雷解によつて 陰極にアルカリダ生成する樣な湯合には、電流密度が劣

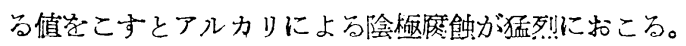

そこで海水などの様な㙏類水溶液に対する防蝕写目標 とする。アルクラツドの被覆材の選択においては注意が 必要である。往来このことがあ恋りはつきりして居なか つたのゼ、アルクラツドの被覆材は、単に他のヂェラル ミンより電位が低ければよく、両者の電位差が大きい注 ど保護作用が大きいなどと云われ、甚しいのではマグ ネシウムによりアルミニウムが保護されるとの考えさへ めつた。(2)実用されて居るアルクラツド板で、他のヂュ ラルミンにアルミニウム家被覆材として局るものは、上 の事実学知らない作ら丁度よい大さの電流を生ずる様な

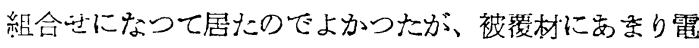
位の低いもの存使うと、かえつて侵されることになる。

しかし除植の電解生成物が水素だけである梯な溶液の

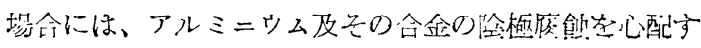
る必要はなくな念のである。

\section{熋考文献}

(1) E. Cumberland : Tr. Favady Soc.11 (1951), $277 \sim 81$

G. Harker, J. Mc. Namara : Soc. Chem. Ind. $29(1910), 1286$

(2) G. W. Akinow : Tr. of the Central Aero-Hydrody. Inst. 70 (1931), 1

G. W. Akimow : Kor. Niet, 84 (1930)

(3) P. Brenner : Z. Metallk., 29 (1937), 334

W. Geller : Z. Metallk., 31 (1939), 365

H. Kostron : Alu:ninium, 23 (1941), 195

(4) F. C. Althof, S. Rastock, Kor. n. Niet., $16(1940), 217$

W. Bungardt : Z. Metalk., 32 (1940), 363

(5) U. R. Evans. T. P. Hoar : Proc. Roy. Soc. (London), A 137 (1932), 343

R. B. Niears, R. H. Brown : Tr. Electrochem. Soc., 74 (1938), 495

(6) B. R. Nears, R. H. Brown : Tr. Electro:hem. Soc., 74 (1938), 519

(7) B. P. Cladwell, V. J. Albano : Tr. Electrock:em. Soc. 76 (1939), 271

(8) I. R. Ergang, G. Masing : Nachr. Akad. Wiss. Göttinger Niath-physik Klasse. Niath-physikchem. Abt. 13 (1946)

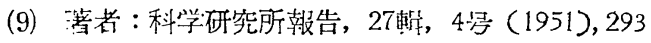

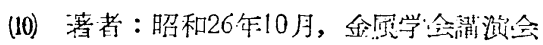

(11) 䓔考: 科学研究所報告, 24輯, 7是 (1948), 375

(12) 著者：科学研究所報告，27輯 2号 (1951)，67

(13) R. B. Mears, R. H. Brown : Ind. Eng. Chem. 29 (1937)

（14）著者：昭和27年 4 月金属学会講演会 